\title{
Diversity and community composition of aquatic ascomycetes varies between freshwater, estuarine and marine habitats in western Scotland
}

\author{
Friggens $\mathrm{NL}^{1}$, Taylor $\mathrm{JE}^{2}$ and Koukol $\mathrm{O}^{3}$ \\ ${ }^{1}$ University of Edinburgh, West Mains Road, EdinburghEH9 3JN nlf1@hw.ac.uk \\ ${ }^{2}$ Royal Botanic Gardens Edinburgh, 20 Inverleith Row, Edinburgh EH3 5LR jtaylor2@rgbe.ac.uk \\ ${ }^{3}$ Faculty of Science, Charles University, Benátská 2, CZ-128 01 Prague, Czech Republic \\ ondrej.koukol@natur.cuni.cz.
}

Friggens NL, Taylor JE, Koukol O. 2017 - Diversity and community composition of aquatic ascomycetes varies between freshwater, estuarine and marine habitats in western Scotland. Mycosphere 8(9), 1267-1287, Doi 10.5943/mycosphere/8/9/2.

\begin{abstract}
Aquatic ascomycetes occur in freshwater and marine environments where they facilitate nutrient cycling and energy flow through the water column, and are the foundations of aquatic food webs. This study investigates the diversity and abundance of aquatic ascomycetes on submerged wood in freshwater, estuarine and marine habitats in north-west Scotland. The fresh water habitat exhibits lowest temperature and salinity with an increasing gradient through the estuarine and marine habitats. Morphological identification and molecular analysis were used to identify taxa. A detailed description is given for Sporoschisma juvenile and Chalara anamorph of Calycina parilis and their phylogenetic placement is discussed based on their morphological variability and both ITS and LSU rDNA. Diversity of aquatic ascomycete taxa decreased along temperature and salinity gradients, being lowest in the estuarine and marine habitats. The composition of fungal communities varied between the three sampled habitats with some taxa common to all three and others exclusive to one habitat. A wide range of biotic, abiotic and anthropogenic factors affect aquatic fungal diversity. It is therefore important to improve our understanding of these effects on aquatic fungal diversity to successfully conserve aquatic ecosystems in light of changing global environments.
\end{abstract}

Key words - Abiotic factors, biodiversity, Chaetosphaeriaceae, lignicolous, Shannon index

\section{Introduction}

Fungi play an important role influencing productivity and biodiversity of both terrestrial and aquatic ecosystems (van der Heijden et al. 1998, Wong et al. 1998, Geraldes et al. 2012). There has been a long and continuing tradition of research into aquatic fungi and new species are still being discovered (e.g. Réblová et al. 2014, 2015, 2016, Fournier et al. 2015, Zhang et al. 2015, Luo et al. 2016) The importance of these organisms in secondary metabolite production has also been recognised (Jones 2011). Despite the UK being the home to C.T. 
Ingold who discovered aquatic hyphomycetes, there are relatively few studies on aquatic lignicolous ascomycetes or aquatic hyphomycetes (Willoughby \& Archer 1973, Iqbal \& Webster 1977, Shearer \& Webster 1985a, 1985b, 1991, Kane et al. 2002, Pearman et al. 2010) which grow mainly on woody substrates and as a result the diversity of these fungi in aquatic habitats in the UK is relatively unexplored. Recent studies estimate total fungal biodiversity at 3.5-5.1 million species (O'Brien et al. 2005, Richards et al. 2012), while aquatic fungal diversity has been estimated at 3000-4145 species (Shearer et al. 2007, Jones et al. 2014). These estimates highlight the relatively low fungal diversity in aquatic as compared to terrestrial habitats (Bärlocher \& Boddy 2016), which may truly be due to a wide range of biotic and abiotic factors or may be merely an artefact of low sampling effort in aquatic environments (Richards et al. 2012). However, the study of metagenomics using high throughput sequencing may mean that biodiversity estimates need to be revisited (Bärlocher \& Boddy 2016).

Aquatic hyphomycetes are adapted to lotic freshwater environments growing on dead plant material such as leaf litter (Ingold 1942, Medeiros et al. 2009, Fernandes et al. 2012) and submerged lignicolous material (Yuen et al. 1998, Vijaykrishna et al. 2006, Shearer et al. 2007, Kuehn 2016). Sexual ascomycetes also display adaptations to aquatic environments (Willoughby \& Archer 1973, Pearman et al. 2010), and facilitate decomposition and softening of lignicolous wood substrates (Hyde et al. 2016). Recent evidence suggests that aquatic hyphomycetes can survive and grow outside aquatic environments for a part of their lifecycle (Chauvet et al. 2016), e.g. with an endophytic phase in tissues of terrestrial plants (Sokolski et al. 2006, Selosse et al. 2008, Seena \& Monroy 2016). Many ascomycetes recorded in aquatic habitats are migrants from terrestrial habitats (Vijaykrishna et al. 2006, Shearer et al. 2007).

The aim of this research is to elucidate the diversity and abundance of aquatic fungi in three different habitats in north-west Scotland through morphological and molecular identification of taxa. The hypothesis is that the abundance and diversity of aquatic fungi will be different between the three habitats. A similar study was undertaken previously in Scotland on the east coast in an area close to human habitation (Pearman et al. 2010) and studies of aquatic hyphomycetes have been undertaken near the present study (Ingold 1973).

\section{Materials \& Methods \\ Sample collection}

Wood samples were collected on $17^{\text {th }}$ January 2016 at Feochan Bheag $\left(56^{\circ} 21^{\prime} 54.2^{\prime \prime} \mathrm{N}\right.$ $\left.5^{\circ} 26^{\prime} 17.2^{\prime \prime} \mathrm{W}\right)$ and Barrnacarry Bay $\left(56^{\circ} 20^{\prime} 45.9^{\prime \prime} \mathrm{N} 5^{\circ} 32^{\prime} 38.5^{\prime \prime} \mathrm{W}\right)$ in the north west of Scotland. Fifty samples of submerged or recently submerged wood were collected from each site. Wood originating from a variety of tree species of varying sizes were collected in order to maximise diversity of aquatic fungi found. Five subsites were selected along a $200 \mathrm{~m}$ transect along the water's edge at the river and estuary sites (Feochan Bheag). Five to 20 samples of submerged wood were collected from each subsite. Wet wood samples were collected evenly along a 200m stretch of beach, below the high tide mark to ensure the wood had been recently submerged. Water samples were collected for incubation and to make culture media. Wood samples were immediately sealed in individual labelled plastic bags to avoid contamination. The bagged wood samples were stored at $4^{\circ} \mathrm{C}$ until examination.

At the three sampled habitats (marine, estuarine and freshwater), abiotic variables of the waterbody were measured to investigate the environmental conditions of each habitat. At each sampling subsite measurements of water $\mathrm{pH}$, temperature $\left({ }^{\circ} \mathrm{C}\right)$ and electrolytic conductivity $(\mu \mathrm{S} / \mathrm{m})$ were taken using a HANNA H1991300 instrument (Rhode Island, USA). The HANNA instrument was calibrated directly prior to sampling at each subsite using prescribed HANNA calibration solutions. Electrolytic conductivity was used to measure dissolved ion content of solutions (Gray 2014) estimating salinity (Lewis \& Perkin 1978) and will be referred to as salinity hence forth. For marine salinity measurements, a figure of 
$>3999 \mu \mathrm{S} / \mathrm{m}$ is used as this was the maximum range of the HANNA instrument and all five marine salinity measurements were $>3999 \mu \mathrm{S} / \mathrm{m}$. In order to estimate the salinity of seawater samples, laboratory dilutions were generated giving an estimated salinity of $\approx 4580 \mathrm{mS} / \mathrm{m}$. This corresponds with general estimates of salinity ranging from $5.5 \mu \mathrm{S} / \mathrm{m}$ in deionized water to $5000 \mathrm{mS} / \mathrm{m}$ in seawater (Lenntech 2016).

\section{Specimen examination and culturing}

The whole surface of each sample was examined individually under a dissection microscope twice over five weeks (between $19^{\text {th }} \mathrm{Jan}-25^{\text {th }}$ Feb 2016). Microscopic observations were made of all fungi found and images captured with a Leica Microsystems DHC450 digital camera mounted on a Leitz Dialux 20 light microscope with DIC objectives and a Wild Makroskop M420 stereomicroscope for fungi on the substrata.

For all fungi recorded, single spore isolations were attempted on 5\% w/v Malt Extract Agar (MEA, Fluka, Sigma Aldrich, Germany) supplemented with 0.3 g/L streptomycin sulphate (Sigma Aldrich, Germany). Once germinated, spores were sub-cultured on to similar MEA media made using distilled water or seawater from Barrnacarry Bay. River and estuary fungi were grown on distilled water MEA and marine fungi were grown on seawater MEA. The cultured fungi were then stored on their respective plates at $4{ }^{\circ} \mathrm{C}$ and used for DNA extraction, PCR and sequencing. Herbarium specimens and DNA were deposited at E and EDNA respectively, and cultures stored at RBGE or deposited at MFLUCC.

\section{DNA extraction, PCR and sequencing}

Cultured fungi were excised from the surface of the plates and placed in $1.5 \mathrm{ml}$ Eppendorf tubes and homogenised using sterile micro-pestles, acid washed sand and $50 \mu 12 \%$ CTAB. Micro-pestles where rotated at high speed using a small electric drill. A CTAB extraction was then undertaken (Cubero et al. 1999) with an initial step of extended incubation in a SmartBlock (Eppendorf, UK) for 1 hour at $800 \mathrm{rpm}$ and bench top incubation of DNA in $600 \mu \mathrm{l}$ ice cold propanol for 30 minutes to precipitate DNA. The DNA pellet was finally dissolved in $50 \mu \mathrm{l}$ TE buffer $\left(10 \mathrm{mM}\right.$ Tris, $1 \mathrm{mM}$ EDTA) and stored at $-20^{\circ} \mathrm{C}$. Extracted DNA was used as templates for PCR using the forward ITS1F (5' - CTT GGT CAT TTA GAG GAA GTA A - 3') (White et al. 1990) and reverse ITS4a (5' - CGC CGT TAC TGG GGC AAT CCC TG - 3') (Larena et al. 1999) primers amplifying the internal transcribed spacers of ribosomal DNA (further referred to as ITS) and NL1 (5'- GCA TAT CAA TAA GCG GAG GAA AAG - 3') and NL4 (5'- GGT CCG TGT TTC AAG ACGG - 3') primers amplifying the large subunit of ribosomal DNA (LSU) (O'Donnell 1993). A $20 \mu \mathrm{l}$ PCR reaction mixture containing $2 \mu 110$ $\times$ reaction buffer, $0.6 \mathrm{ul} \mathrm{MgCl}_{2}(50 \mathrm{mM}), 2 \mu \mathrm{l}(2 \mathrm{mM})$ deoxyribonucleotide triphosphate $(\mathrm{dNTP}$ mix) (Bioline, UK), $0.75 \mu \mathrm{l}$ of ITS1f and ITS4A $(0.3 \mu \mathrm{M})$ each and $0.2 \mu \mathrm{l}$ of Taq DNA polymerase (Bioline, UK), $4 \mu 15 \times$ trehalose, bovine serum albumin (BSA), and polysorbate20 (Tween-20)(TBT-PAR) and template DNA (1 $\mu \mathrm{l})$. PCR was carried out in a programmed thermocycler (BioRad Tetrad2) with the following PCR conditions $\left(3\right.$ minutes at $95^{\circ} \mathrm{C}, 35$ cycles $\left(45\right.$ seconds at $94^{\circ} \mathrm{C}, 1$ minute at $52^{\circ} \mathrm{C}, 90$ seconds at $\left.72^{\circ} \mathrm{C}\right), 5 \mathrm{~min}$ at $72^{\circ} \mathrm{C}$ ). Remaining primers were removed by adding $2 \mu 1$ of ExoSAP-IT (Affymetrix, California, USA) to $5 \mu 1$ of the PCR product. Sequencing reactions were conducted for both primers with $1 \mu$ of clean product using BigDye Terminator v3.1 Cycle Sequencing Kit (Applied Biosystems, USA) following the protocol provided. The PCR products were sequenced at Edinburgh Genomics (Genome Science, The King's Buildings, Edinburgh).

\section{Phylogenetic analysis}

Sequences generated by Edinburgh Genomics were trimmed and aligned using Sequencher 5.1 (Gene Codes Corporation, Michigan, USA). Sequencher assembled FASTA files which were entered into UNITE database (Kõljalg et al. 2013) and BLASTn (Altschul et 
al. 1990). Assembled ITS and LSU sequences with selected BLASTn matches where aligned using the MAFFT algorithm implemented in Geneious 6.1.5 software and manually edited in the same software. Phylogenetic analyses were performed independently for both ITS and LSU datasets by Bayesian inference using MrBayes version 3.2 (Ronquist et al. 2012) and by maximum likelihood analysis using MEGA7 (Kumar et al. 2015). For the Bayesian analysis, the best-fit model was determined using jModeltest version 2.1.5 (Darriba et al. 2012). Two independent runs of 3,000,000 generations were run with sampling every 100th generation, with the first $25 \%$ of samples discarded as burn-in. Posterior probabilities (PP) were used as Bayesian branch support for consensus trees. The average standard deviation of split frequencies estimating convergence reached the level of 0.002 at the end of the analyses.

\section{Statistical analysis}

Abiotic and taxa data were analysed using one-way analysis of variance (ANOVA), Students T-test and regression analyses yielding $\mathrm{R}^{2}$-values using Microsoft Excel 2013. The following equations were used to calculate the diversity and similarity of the three sampled habitats based on collected presence/absence data: Shannon Index of Biodiversity (H) (Shannon \& Weaver 1949, Pielou 1966, Keylock 2005), Max H (Peet 1975), Sørensen's Similarity Index (Sørensen 1948), Euclidean distance with n dimensions (Krebs 2014).

\section{Results}

\section{Abiotic variables}

No statistically significant difference $(\mathrm{P}<0.05)$ was found between $\mathrm{pH}$ at the river and estuary sites (Fig. 1). The marine site was found to have a significantly higher $\mathrm{pH}$ than the river and estuary. Statistically significant differences were found between the temperatures of each habitat. This indicates that a temperature gradient exists across the habitats from low $\left(3.89^{\circ} \mathrm{C}\right.$ river) to high $\left(7.02^{\circ} \mathrm{C}\right.$-marine). Statistically significant differences were found between all three habitats indicating that a salinity gradient exists from low $(102.40 \mu \mathrm{S} / \mathrm{m}$-river $)$ to high (>3999 $\mu \mathrm{S} / \mathrm{m}$-marine). One outlier was removed from the estuary electrical conductivity data set and excluded for all analysis.

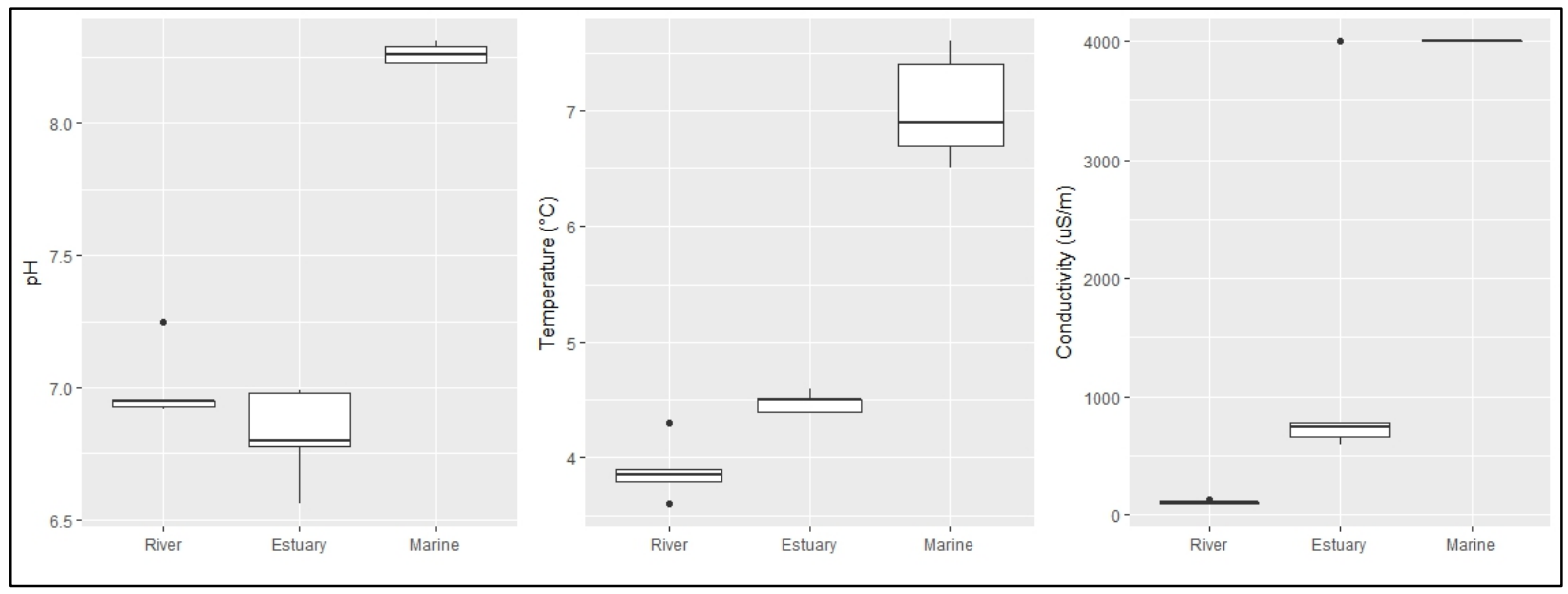

Fig. 1 Abiotic variable measured at the river, estuary and marine sites.

\section{Aquatic ascomycete abundance and diversity}

The fungi recorded were identified using morphological traits and molecular DNA identification. Due to the challenging nature of identifying aquatic fungi not all taxa were successfully identified to species level (Table 1). The number, and composition, of species 
recorded varied between habitats. The Shannon Index of Biodiversity indicated that biodiversity of all sampled habitats was very similar and fell within a 0.23 range (Table 2). Fungal biodiversity at the river habitat was the highest of the three sampled habitats, whereas the estuary and marine habitats had lower $\mathrm{H}$-values and therefore lower biodiversity. The maximum diversity using Shannon Index (MaxH) is achieved when each individual is a different species, therefore the $\mathrm{H}$-values may be viewed proportionally to their maximum. When viewed proportionally the marine and estuary had a higher $\%$ of maxH than the river habitat. Notably all studied habitats had a high \% of maxH and therefore high estimated diversity.

The river, estuary and marine habitats fell along a temperature and salinity gradient which may have affected diversity and distributions of aquatic fungi. This can be visualised by comparing aquatic fungal diversity $(\mathrm{H})$ with salinity and temperature at each habitat (Fig. 2). The aquatic fungal biodiversity decreased along an increasing temperature gradient (Fig. 2B). Similarly, aquatic fungal biodiversity decreased along an increasing salinity gradient (Fig. 2A). Care must be taken when interpreting these data, as previously stated, the difference in biodiversity between sampled habitats was minor. Therefore, extrapolation of any regressions (Fig. 2) must be undertaken cautiously, if at all.

\section{Similarities and differences between habitats}

To elucidate how similar the three habitats are Sørensen's Similarity Index was used. Of the three sampled habitats, the river and estuary were most similar and the estuary/marine and river/marine habitats were least similar (Table 3). The Sørensen's Similarity Index only considers the presence/absence of taxa however, Euclidean distance incorporates diversity and abundance data (Krebs 2014). Based on Euclidean distance the most similar habitats were the estuary and marine while the least similar were the river and marine habitats (Table 3). This result contradicts that obtained using the Sørensen's Index and highlights the difference between presence/absence and abundance data.

Many species were found in all three habitats, including: Chalara state of Calycina parilis, Helicosporium griseum and Neonectria lugdunensis. However, approximately $60 \%$ of all taxa were found in one habitat only, highlighting the difference in taxa distribution and community composition between the three habitats reflecting the abiotic conditions. No taxa were found in both estuary and marine habitats alone (Fig. 3), whereas two taxa are found in both river and marine habitats, but excluding the estuary.

\section{Taxonomy}

Chalara state of Calycina parilis (P. Karst.) Kuntze Revis. gen. pl. (Leipzig) 3(2): 448 (1898)

\section{Facesoffungi number: FoF 03441}

Fig. 4

Saprobic on dead wood submerged in a river. Sexual morph: Not observed in the present study. Asexual morph: Colonies effuse, sparse, pale brown, finely hairy. Phialides formed directly on the vegetative hyphae, mostly separated by a septum. Phialides narrowly lageniform, light brown, smooth or faintly verruculose around venter, gradually tapering towards the collarette (39)42-48(51) $\mu \mathrm{m}$. Venter subcylindrical to subconical, (19)21-28(30) $\times(5) 6-8.5(10) \mu \mathrm{m}$. Collarette cylindrical, light brown, (22.5)23-27(29) $\times(3.5) 4-5.5(6) \mu \mathrm{m}$. Proliferation was not observed. Transition from venter to collarette gradual, with no constriction at the transition. Ratio of the mean lengths of collarette and venter is 1:1. 
Table 1. The diversity of aquatic fungi found on wood samples from three sampled habitats. All GenBank accession numbers refer to ITS sequences unless stated otherwise.

\begin{tabular}{|c|c|c|c|c|c|}
\hline Taxa & $\begin{array}{c}\text { River } \\
\text { FeochanBeagh }\end{array}$ & $\begin{array}{c}\text { Estuary } \\
\text { FeochanBeagh }\end{array}$ & $\begin{array}{c}\text { Marine } \\
\text { Barrnacarry }\end{array}$ & $\begin{array}{c}\text { GenBank } \\
\text { Accession no. }\end{array}$ & $\begin{array}{c}\text { E Herbarium } \\
\text { no. }\end{array}$ \\
\hline Acrogenospora sphaerocephala (Berk. \& Broome) M.B. Ellis & 2 & 1 & 0 & - & - \\
\hline Anguillospora longissima (Sacc. \& P. Syd.) Ingold & 2 & 0 & 0 & - & E00817138 \\
\hline Arbusculina irregularis (R.H. Petersen) Marvanova \& Descals & 9 & 2 & 1 & - & E00817137 \\
\hline Chalara state of Calycina parilis & 16 & 6 & 2 & $\begin{array}{c}\text { MF110620 } \\
\text { MF114107(LSU) }\end{array}$ & E00817143 \\
\hline Clohesyomyces aquaticus K.D. Hyde & 2 & 0 & 0 & MF110612 & E00817159 \\
\hline Clonostachys sp. 1 & 0 & 1 & 0 & - & - \\
\hline Clonostachys sp. 2 & 1 & 0 & 0 & MF110611 & - \\
\hline Cosmospora sp. & 0 & 0 & 1 & - & - \\
\hline Cryptocoryneum condensatum (Wallr.) E.W.Mason \& S. Hughes & 0 & 0 & 3 & - & - \\
\hline Cumulospora marina I. Schmidt & 0 & 0 & 1 & - & - \\
\hline Cylindrocarpon sp. & 3 & 2 & 0 & - & E00817148 \\
\hline Fusarium sp. & 5 & 1 & 2 & - & - \\
\hline Graddoina coracina (Bres.) Dennis & 2 & 0 & 0 & MF110614 & E00817149 \\
\hline Helicosporium griseum Berk. \& M.A. Curtis & 9 & 1 & 2 & - & $\begin{array}{l}\text { E00817141 } \\
\text { E00817150 }\end{array}$ \\
\hline Kirschsteiniothelia arta (Corda) D. Hawksw. & 0 & 0 & 1 & - & - \\
\hline Menispora glauca (Link) Pers. & 2 & 0 & 0 & - & - \\
\hline Mycoarthris corallina Marvanonva \& P.J. Fisher & 6 & 2 & 1 & - & - \\
\hline Mycocentrospora acerina (R. Hertig) Deighton & 3 & 0 & 0 & - & E00817147 \\
\hline Neonectria lugdunensis J. Webster & 13 & 9 & 9 & $\begin{array}{c}\text { MF110613* } \\
\text { MF110615 } \\
\text { MF110617 } \\
\text { MF110618 } \\
\text { MF110619 }\end{array}$ & $\begin{array}{c}\text { E00817140 } \\
\text { E00817151 } \\
\text { E00817145 } \\
- \\
-\end{array}$ \\
\hline Phomatospora luteotingens J. Fourn. \& Lechat & 3 & 2 & 0 & $\begin{array}{l}- \\
-\end{array}$ & $\begin{array}{l}\text { E00817139 } \\
\text { E00817152 }\end{array}$ \\
\hline Sporochisma juvenile Boud & 1 & 0 & 0 & $\begin{array}{l}\text { MF110610 } \\
\text { MF114106 } \\
\text { (LSU) }\end{array}$ & $\begin{array}{c}\text { E00817146 } \\
-\end{array}$ \\
\hline Taeniolella exilis (P. Karst.) S. Hughes & 0 & 0 & 1 & & - \\
\hline Tetracladium setigerum (Grove) Ingold & 0 & 0 & 3 & MF110616 & - \\
\hline Trichoderma sp. & 0 & 1 & 0 & - & - \\
\hline Xylohypha ferruginosa (Corda) S. Hughes & 1 & 0 & 1 & - & - \\
\hline Unidentified coelomycete 1 & 0 & 1 & 0 & - & - \\
\hline Unidentified hyphomycete 1 & 0 & 3 & 0 & - & \\
\hline
\end{tabular}

*Note: In the case of Neonectria lugdunensis GenBank accession numbers do not correspond with E Herbarium numbers as different specimens were used. 
Conidia one-celled, hyaline, smooth, thick-walled, mostly cylindrical with obtuse ends, (5.5)7$9(10) \times(3) 3.5-4(4.5) \mu \mathrm{m}$ in size. The mean conidium length/width ratio is $2.2: 1$. Conidia are extruded in dispersible chains.

Culture characteristics: Colony irregular, umbonate, velvety white with undulate margin on MEA, reaching $8-10 \mathrm{~mm}$ in diameter in 21 days at $25^{\circ} \mathrm{C}$, sporulating abundantly. Conidiophores straight to bent, formed by 1-3 pale brown cells and terminated by a phialide. Phialides lageniform, straight, bent or flexuous, smooth or irregularly faintly verruculose around venter, reaching (31.5)33.5-47(51.5) $\mu \mathrm{m}$. Venter subcylindrical, 18-25(28.5) ×3.5-6.5 $\mu \mathrm{m}$. Collarette cylindrical 11-26.5(31.5) $\times 2-3 \mu \mathrm{m}$. Conidia cylindrical to clavate, both ends rounded to slightly truncate, hyaline, aseptate, smooth-walled 3.5-6.5 $\times 1.5-2.5 \mu \mathrm{m}$. Occasionally clavate to almost ovoid conidia $2.5-3 \mu \mathrm{m} \times 1.5-2 \mu \mathrm{m}$ are produced and form false chains. The mean conidium length/width ratio is 2.6:1. Conidia are extruded in short dispersible chains.

Material examined: Scotland, Argyll and Bute, Oban, Feochan Bheag (56 21'54.2"N $5^{\circ} 26^{\prime} 17.2^{\prime \prime} \mathrm{W}$ ), on wood submerged in freshwater stream, 17 January 2016, N. Friggens \& J. Taylor (Ri3.1) E00817143; EDNA16-0044153; LSU: MF114107; ITS: MF110620; Culture: MFLUCC 17-2057.

There are several studies which either describe species of Chalara from freshwater habitats (McKenzie et al. 2002) or record their presence (Baschien et al. 2008, Tsui et al. 2001), including in the UK (Willoughby \& Archer 1973) where a species of Chalara was recorded on Alnus. However, none of the studies including keys provided by Nag Raj \& Kendrick (1975) or McKenzie et al. (2002) led to a species with identical morphology. The affinity of the anamorph recorded in our study to Calycina/Pezizella sequences in GenBank drew our attention to species with known Chalara anamorphs recorded from aquatic habitats. Calycina lactea (Sacc.) Baral, R. Galán \& Platas occurs in the same habitat, but has smaller conidia (2$2.5 \times 2 \mu \mathrm{m}$, H.-O. Baral, pers. com.) and is phylogenetically distinct (Fig. 5). Not represented in GenBank is Calycina parilis, (syn. Pezizella parilis (P. Karst.) Dennis) that has been recently collected on Fagus (?) wood in a stream in Hades, near Holmfirth, Yorkshire, UK in 2011, and has a similar anamorph to our collection (Calycina parilis Ascofrance, 07-03-2012, C. Yeates, unpublished). The presence of Chalara anamorph in "intimate association" with P. parilis (as P. parile) was mentioned by Dennis (1964), though without detailed description. Svrček (1984) in his revision of species described by J. Velenovský found $P$. parile conspecific with Helotium glochidiatum Velen. described from twig of Cratageus sp. in a stream. Svrček (1984) provided short description of the Chalara anamorph including measurements. According to his observation, the anamorph produced conidiophores of "lageniform shape, pale brown coloured, 25-35 $\times 5-7 \mu \mathrm{m}$ large, $2.5-3.5 \mu \mathrm{m}$ thick above, producing cylindrical, hyaline conidia 3.5-10 $\times 1.5-2.5 \mu \mathrm{m}$, truncate at both ends". Though these dimensions are smaller compared to ours, this can be attributed to the common variability of Chalara species (Koukol 2011). Though there are no sequences of $C$. parilis currently in GenBank, all other characteristics point to $C$. parilis as a proper name for our fungus, so a full description of the anamorph is given here together with phylogenetic placement among related species (Fig. 5).

Table 2. Calculated Shannon Index values $(\mathrm{H})$ and maximum possible $\mathrm{H}$ for each habitat sampled.

\begin{tabular}{lccc}
\hline Habitat & Shannon Index (H) & Max H & \% of max H (\%) \\
\hline River & 2.47 & 4.38 & 56 \\
Estuary & 2.24 & 3.47 & 65 \\
Marine & 2.24 & 3.33 & 67 \\
& & & \\
\hline
\end{tabular}


Table 3. Calculated Sørensen's Similarity Index (S) and Euclidean distance (ED) values for the three sampled habitats.

\begin{tabular}{lccc}
\hline \multicolumn{1}{c}{ ED } & & & \\
S & River & Estuary & Marine \\
\hline River & & 17.44 & 22.20 \\
Estuary & 0.38 & & 8.00 \\
Marine & 0.32 & 0.32 & \\
\hline
\end{tabular}

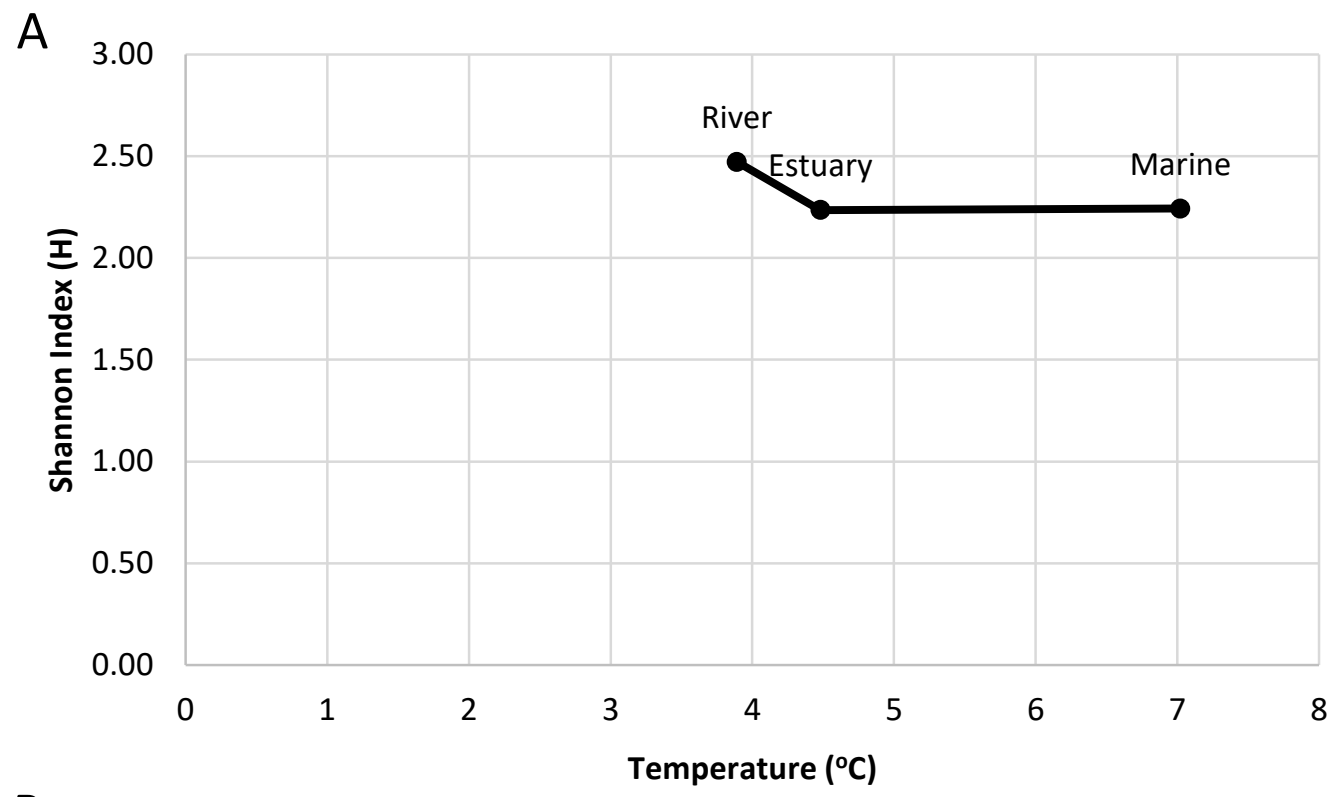

B

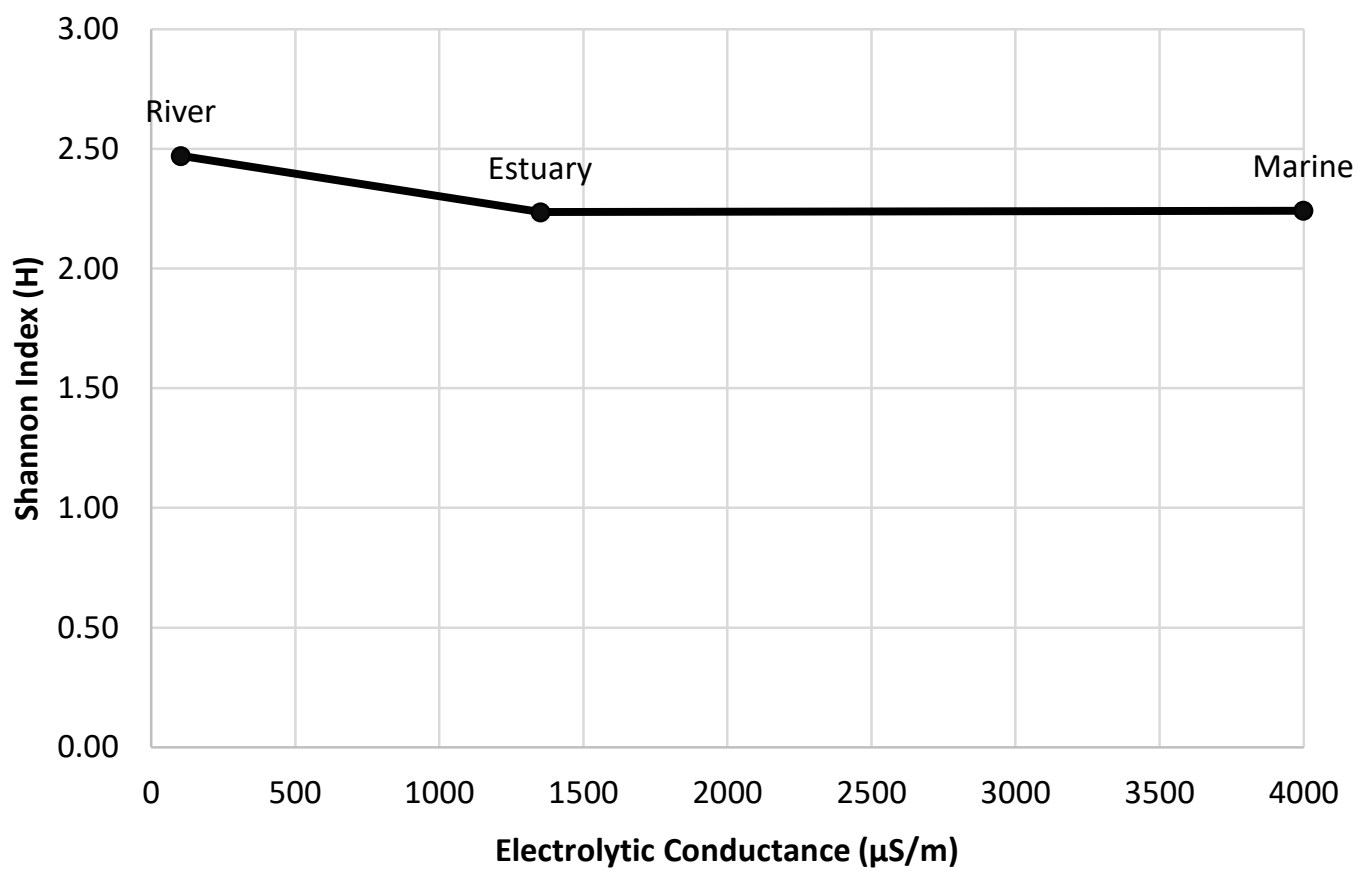

Fig. 2_Aquatic fungal diversity across temperature and salinity gradients. A) Aquatic fungal diversity as calculated by Shannon Index $(\mathrm{H})$ for three different habitats across a previously established salinity gradient. B) Aquatic fungal diversity for the three sampled habitats across a temperature gradient. 


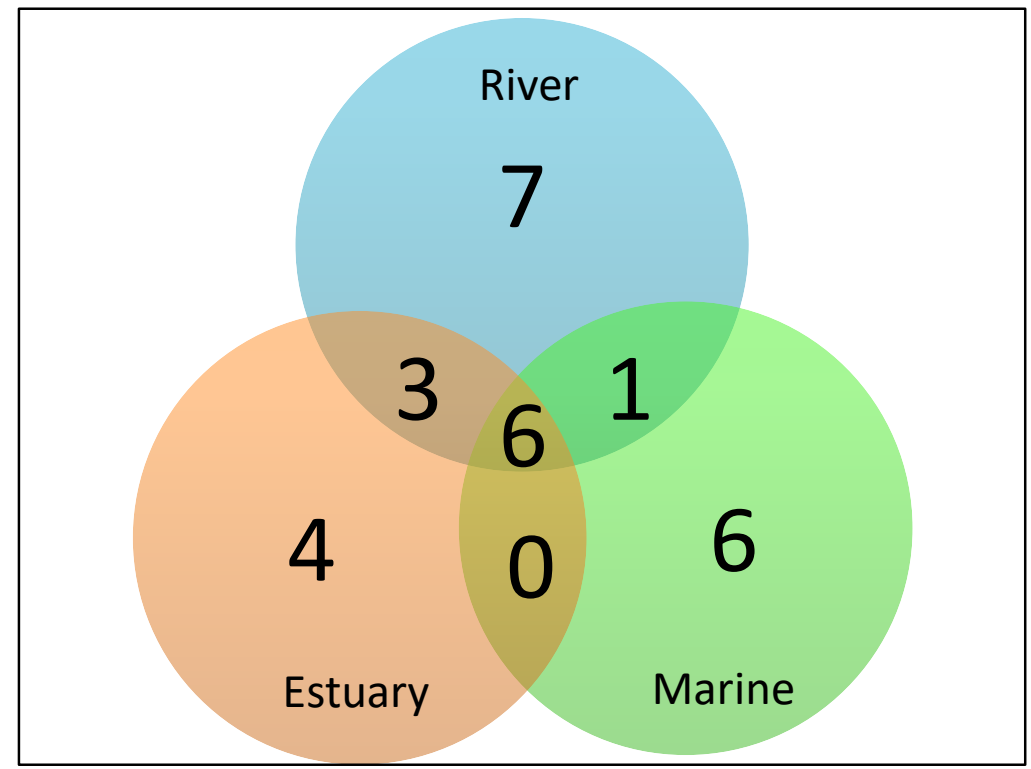

Fig. 3 Venn diagram representing the number of taxa found at each of the three sampled habitats.
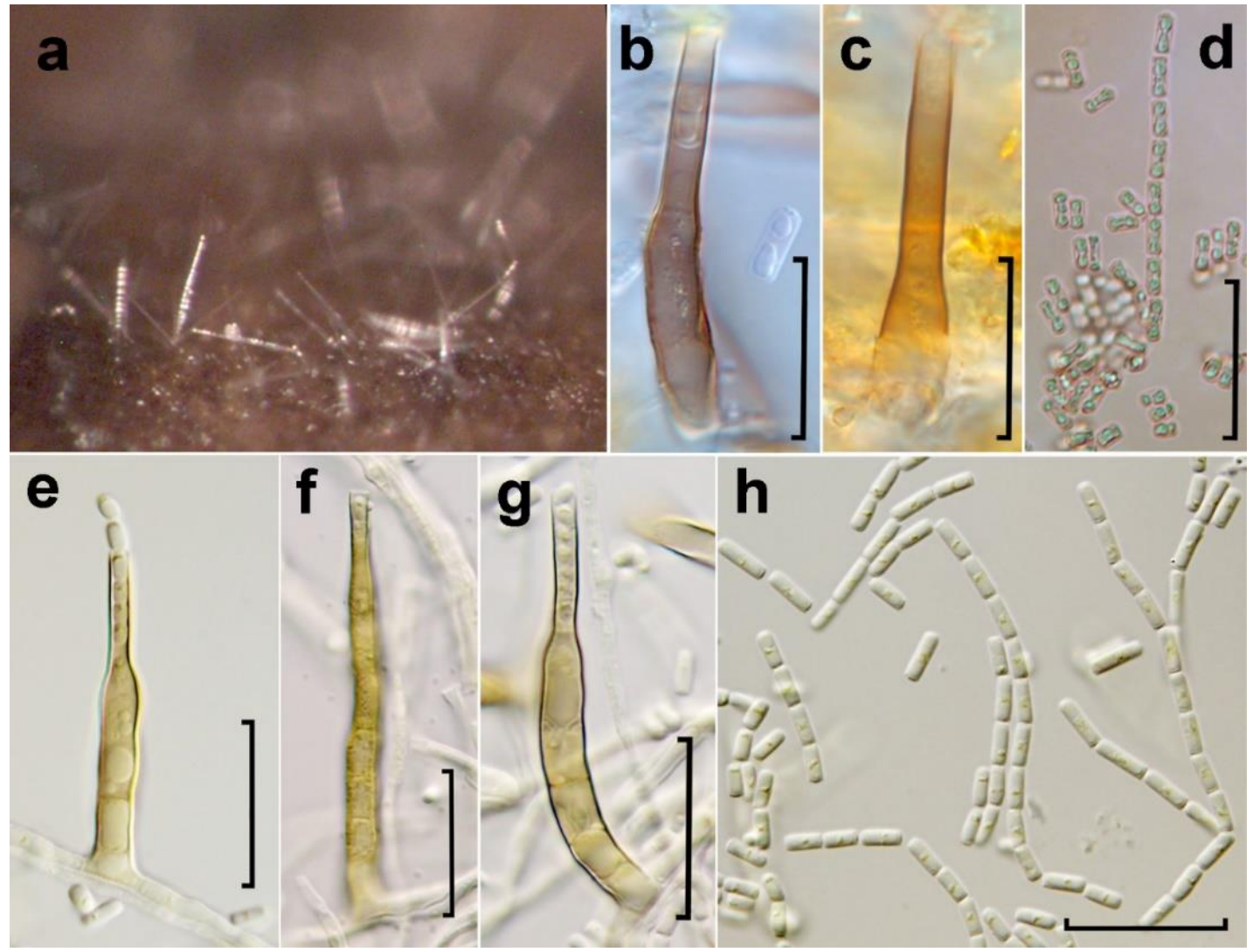

Fig. 4 Chalara state of Calycina parilis on natural substrate (a-d) and from MEA (e-h). a Conidial chains outgrowing from the colony on the substrate. b-c Phialides. d Conidia. e Phialide producing conidial chain. f Phialide with verruculouse surface. g Phialide with clavate conidia. h Conidia. Scale bars: $20 \mu \mathrm{m}$. 


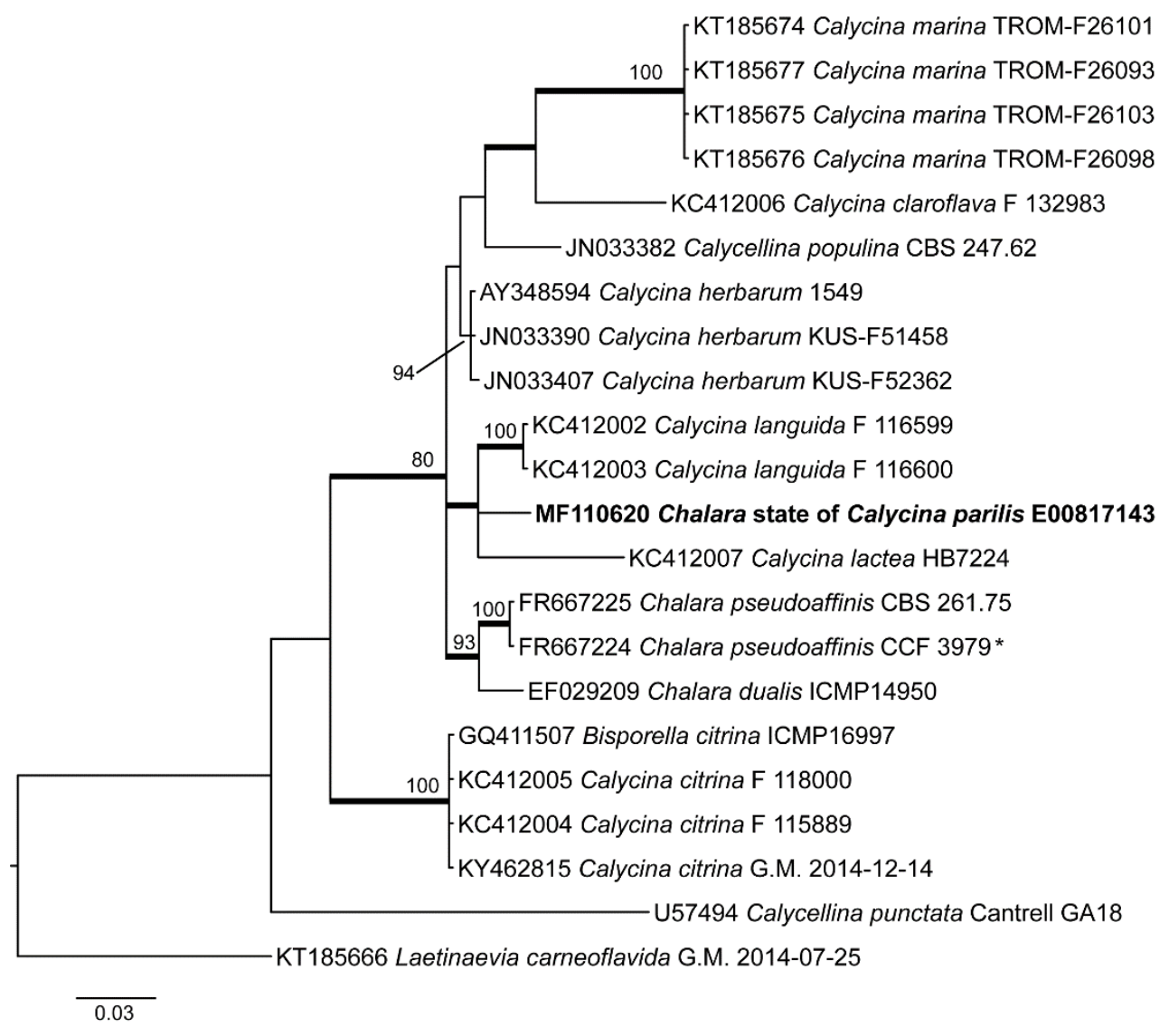

Fig. 5 Phylogenetic tree based on analysis of ITS. Bootstrap support values for Maximum Likelihood greater than $90 \%$ are indicated above the nodes. Bayesian posterior probabilities greater than 0.95 are shown as bold branches. The newly added strain is shown in bold, extype strains are indicated by an asterisk.

Sporoschisma juvenile Boud., Icon. Mycol. (Paris) 1: 12 (1904).

Fig. 6

Facesoffungi number: FoF 03440

Saprobic on dead wood submerged in a river. Sexual morph: Absent. Asexual morph: Colonies effuse, sparse, black, hairy. Setae present, capitate, erect, straight or flexuous, smooth, pale brown, 2-5 septate, paler and narrowing towards the subhyaline apex, 99-135 $\times 5-7 \mu \mathrm{m}$ (in widest part), apex swollen, 6-7 $\mu \mathrm{m}$ wide, with sparse mucilage. Conidiophores mononematous, erect, solitary or aggregated in groups of $2-5$, arising from dark brown reduced basal stroma, unbranched, straight or slightly curved, thick-walled, dark brown, septate, (32)33-44(47) $\times$ 8.5-10(11) $\mu \mathrm{m}($ SDev $5.5 \times 0.5 \mu \mathrm{m})$. Conidiogenous cells monophialidic, terminal, integrated, thick-walled, consisting of a slightly swollen venter (40)44.5-52.5(55) $\times$ 14-21 $\mu \mathrm{m}($ SDev $3.5 \times 2.0 \mu \mathrm{m})$, narrowing abruptly to a long, tubular collarette $(72) 88$ $131.5(137) \times 10-11 \mu \mathrm{m}$ at widest part (SDev $21.5 \times 0.5 \mu \mathrm{m})$, dark brown, slightly paler and frayed at the apex. Conidia cylindrical, occasionally slightly narrower at the base, with minute basal scar and rounded apex, initially non-septate, thick-walled, pale yellowish-hyaline, remaining hyaline for some time after release, becoming pale brown, verruculose and 3-septate, in older released conidia, concolorous, (24)26.5-32.5(37) $\times(7.5) 8.5-10(10.5) \mu \mathrm{m}(\mathrm{SDev} 3 \times$ $0.5 \mu \mathrm{m})$, often in chains.

Culture characteristics: Colony creamy white on MEA, reaching $10-15 \mathrm{~mm}$ in diameter in 21 days at $25^{\circ} \mathrm{C}$. Setae rarely present. Conidiophores similar as on natural substrate with conidiophores reaching (19)23-31 × (5.5)7-11(13) $\mu \mathrm{m}$. Conidiogenous cells slightly shorter, reaching (51.5)60.5-76.5(79.5) (SDev $8 \mu \mathrm{m})$, venter (29)31-36.5(40) $\times(14) 16-21.5$ 
$\mu \mathrm{m}(\operatorname{SDev} 3 \times 1 \mu \mathrm{m})$, collarette (24)25.5-41.5(53.5) $\times 8.5-11.5 \mu \mathrm{m}$ (SDev $8 \times 1 \mu \mathrm{m})$. Conidia cylindrical, with a minute marginal frill at the base, both ends rounded to slightly truncate, hyaline, mostly aseptate, in older cultures with 1-3 septa, smooth-walled (18.5)20-25(28.5) $\times$ (7.5)8-9.5(10.5) $\mu \mathrm{m}(\mathrm{SDev} 2.5 \times 0.5 \mu \mathrm{m})$.

Material examined: Scotland, Argyll and Bute, Oban, Feochan Bheag (56 21'54.2"N $\left.5^{\circ} 26^{\prime} 17.2^{\prime \prime} \mathrm{W}\right)$, on wood submerged in freshwater stream, 17 January 2016, N. Friggens \& J. Taylor (Ri12.3) E00817146 EPITYPE designated here (ex-epitype culture MFLUCC 172058), EDNA16-0045014; LSU: MF114106; ITS: MF110610.

Notes: Sporoschisma juvenile is similar in morphology to another species common in the UK, S. mirabile Berk. \& Broome and was compared against specimens in E (Ex herb musei Britannici, Herb C.E. Broome S. mirabile. Langridge 27 April 1874). However, these have characteristically septate, smooth-walled, brown conidia and the venter is not swollen. For comparison with the description of S. juvenile in Nag Raj \& Kendrick (1975), the phialophore (conidiophore, venter and collarette) measured (178)181.2-209.2(221) $\mu \mathrm{m}$ (SDev $14 \mu \mathrm{m}$ ) and the phialide (venter and collarette) was (131)146-178.6(183) $\mu \mathrm{m}$ (SDev 16.2 $\mu \mathrm{m}$ ), which corresponds with the range given, and also with that given by Hughes (1949). This suggests that while the morphology on the host is consistent, whether the fungus is derived from an aquatic habitat or a terrestrial one, it is very different when the structures are formed in culture, especially in terms of lengths (Table 4), and this difference was illustrated by Hughes (1949).

Although it has been described numerous times, including recently (Holubová-Jechová 1973, Goh et al. 1997, Zelski et al. 2014) the variation shown in culture and the presentation of an ITS sequence justify further treatment here. In addition, after phylogenetic analysis of the ITS and LSU regions of this sample and other species of Sporoschisma from Luo et al. (2016) (Fig. 8), the recently described S. aquaticum Z.L. Luo, H.Y. Su \& K.D. Hyde is, with no doubt, S. juvenile. The ITS and LSU sequences are identical to Luo et al. (2016) who delimited $S$. aquaticum from $S$. juvenile based on shorter conidia $(26-32 \mu \mathrm{m})$, but the description given by Nag Raj \& Kendrick (1975) mentions 20-42 $\mu \mathrm{m}$. Giving the substantial variability on natural substrate vs. in culture and identical ITS and LSU sequences from distant geographical areas, one may not expect cryptic species within $S$. juvenile. Therefore, S. aquaticum is synonymised herein with $S$. juvenile. In addition, as the specimen in the Paris herbarium (NHMN), which Boudier (1904) used to describe this species, cannot be found his illustration is selected as the lectotype as this includes all the necessary characters needed for the correct application of this name (Fig. 7), and the collection E00817146 is being designated as an epitype.

\section{Discussion}

Twenty-six fungal taxa were identified in this study which is low when compared with most freshwater studies (Tsui et al. 2000, Ho \& Hodgkiss 2001, Ho et al. 2002, Tsui \& Hyde 2004), except those in temperate regions (Hyde and Goh 1999, Pearman et al. 2010). The diversity of lignicolous fungi in subtropical and tropical streams appears to be much higher (Tsui et al. 2000, Ho \& Hodgkiss 2001, Ho et al. 2002, Fryar et al. 2004, Tsui \& Hyde 2004). This may be due to the diversity of plants found in the latter habitats or the higher temperatures (Tsui et al. 2001). In accordance with these observed differences there is almost no overlap between our studies and those of tropical and subtropical studies (Tsui et al. 2000, 2001, Tsui \& Hyde 2004, Luo et al. 2016). The habitats investigated in this study fall along temperature and salinity gradients (Figure 1) which may affect fungal diversity and abundance (Shearer 1972). 


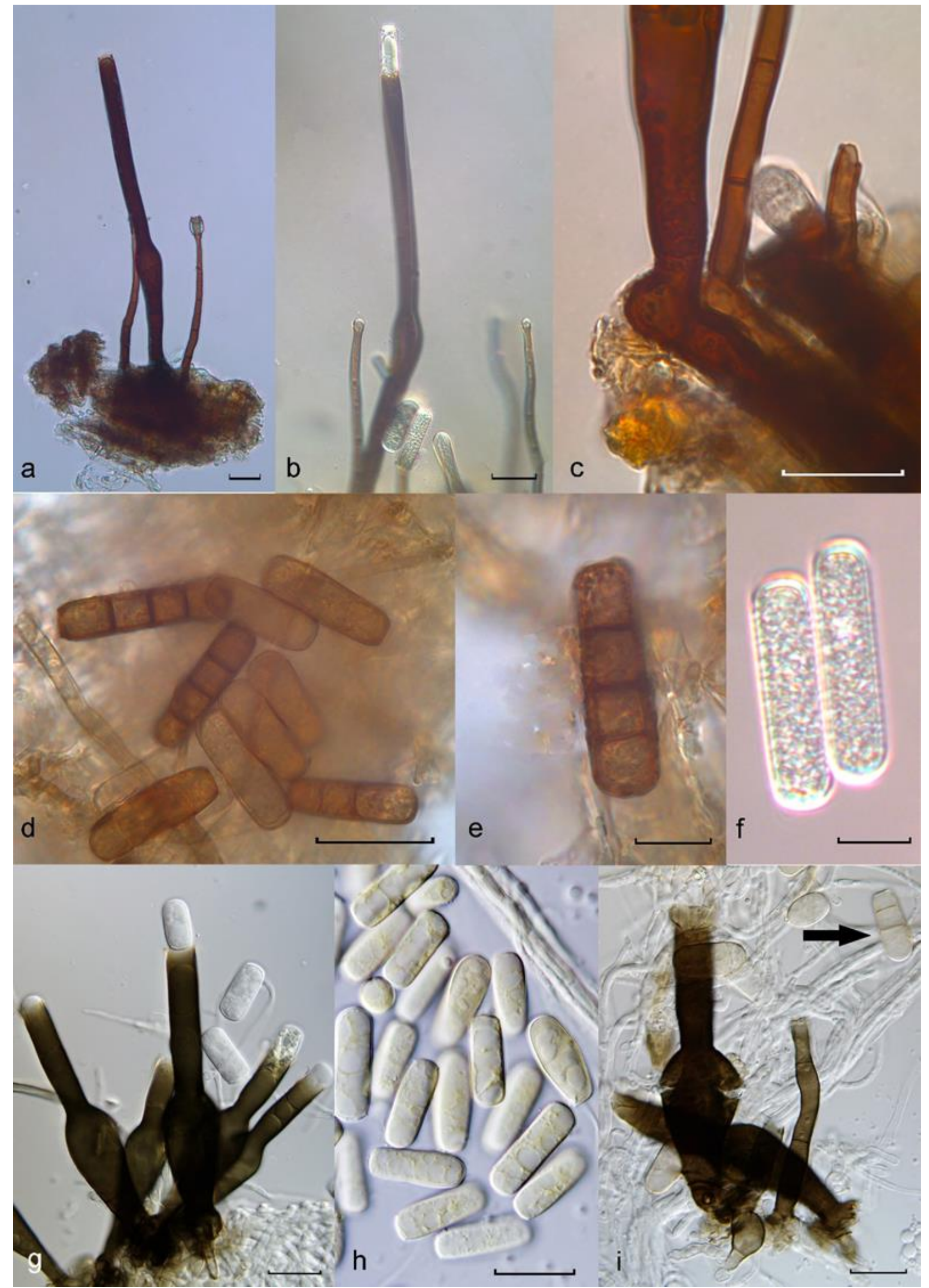

Fig. 6 Sporoschisma juvenile on natural substrate and from MEA. a-b Conidiophore and two setae on the substrate. c Detail of the conidiophore base. d-e mature conidia. $\mathrm{f}$ Immature conidia. g Conidiophores in culture. h Conidia in culture. i Conidiophores, one setae and conidia in older culture ( 3 months), arrow points to septate conidium. Scale bars: $20 \mu \mathrm{m}$. 


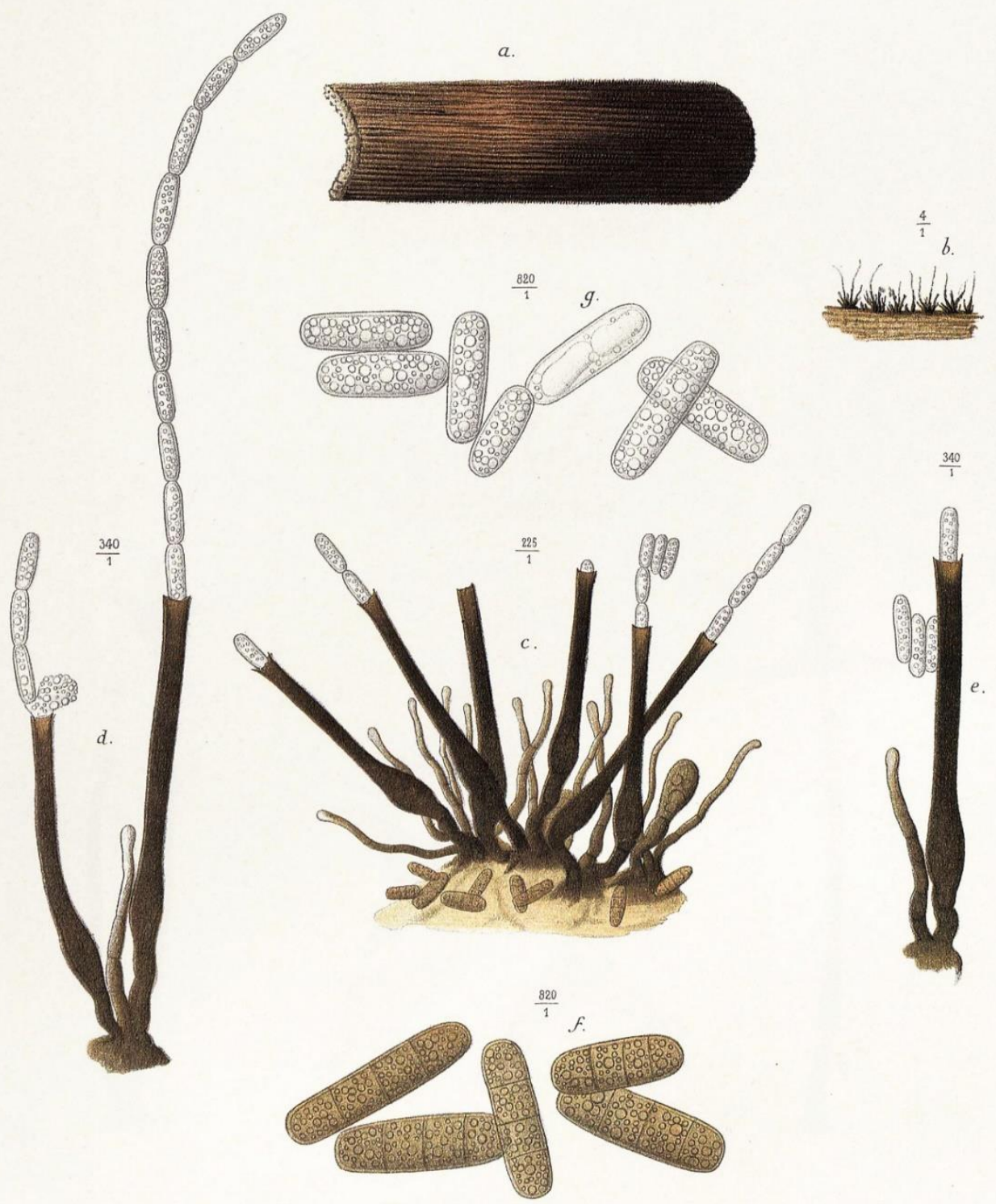

E.Boudier, del,

Fig. 7 Sporoschisma juvenile Boud. Icon. Mycol. (Paris) 1: 12 (1904), Lectotype: Boudier, Icones Mycol. 64 (3), pl. 589 (1904) (lectotype designated here). (C) Editions Piantanida Lausanne, 1981. Permission to publish this image was sought, but efforts to contact the publisher were without success.

All sampled habitats had similar diversity (Table 2) and the range in $\mathrm{H}$ values is much smaller than that found by Pearman et al. (2010) in St. Andrews, Scotland, however the river and estuary habitats had similar H-values. 
Table 4. Variability of $S$. juvenile morphological dimensions found in current and previous work. All measurements in $\mu \mathrm{m}$.

\begin{tabular}{|c|c|c|c|c|c|c|c|c|c|}
\hline & $\begin{array}{c}\text { Phialophore } \\
\text { (conidiophore, } \\
\text { venter, } \\
\text { collarette) } \\
\end{array}$ & $\begin{array}{l}\text { Phialide } \\
\text { (venter, } \\
\text { collarette) }\end{array}$ & Venter & Collarette & Conidiophore & $\begin{array}{l}\text { Collarette: } \\
\text { Venter }\end{array}$ & Conidia & $\begin{array}{l}\text { Length: } \\
\text { Width }\end{array}$ & Setae \\
\hline $\begin{array}{c}\text { In culture } \\
\text { (current study) }\end{array}$ & & $51.5-79.5$ & $29-40 \times 14.1-21.5$ & $24-53.5 \times 8.5-11.5$ & $19-31 \times 5.5-13$ & 1.0:1 & $18.5-28.5 \times 7.5-10.5$ & 2.6:1 & \\
\hline $\begin{array}{c}\text { On host } \\
\text { (current study) } \\
\text { Nag Raj \& }\end{array}$ & $178-221$ & $131-183$ & $40-55 \times 14-21$ & 72-137x 10-11 & $32-47 \times 8.5-11$ & 2.3:1 & $24-37 \times 7.5-10.5$ & $3.2: 1$ & $99-135$ \\
\hline $\begin{array}{l}\text { Kendrick } \\
(1975) \\
\text { Luo et al. } \\
(2016)\end{array}$ & $<240 \times 8-10$ & $90-170$ & $35-55 \times 14-21$ & $52-115 \times 9.5-12$ & & $1.8: 1$ & $20-42 \times 7.5-11$ & $3.4: 1$ & $\begin{array}{l}100- \\
160 \\
127-\end{array}$ \\
\hline S. aquaticum & $183-207 \times 7-9$ & & $\mathrm{x} 15-20$ & x9.5-12.5 & $x 7-9$ & & $26-32 \times 9-10$ & & 141 \\
\hline Hughes (1949) & $150-240 \times 8-10$ & & x 14-21 & $x 9.5-12$ & $x 8-10$ & & $20-42 \times 7.5-11$ & & $\begin{array}{l}100- \\
160\end{array}$ \\
\hline $\begin{array}{c}\text { Boudier } \\
\text { (1904) TYPE }\end{array}$ & $400-800$ & & $\mathrm{x} 20-25$ & & & & $30-45 \times 10-12$ & & \\
\hline
\end{tabular}

Highest diversity in the present study was in the river habitat, with lowest salinity and temperature as observed previously for temperature (Fernandes et al. 2012, Hyde et al. 2016) and salinity (Shearer 1972, Tsui et al. 2001, 2004, Fryar et al. 2004, Pearman et al. 2010, Richards et al. 2012). However, a multitude of factors affect aquatic fungal diversity and a combination of these result in the diversity seen across habitats. Decreasing diversity with increasing temperatures is troubling in light of predicted rising temperatures resulting from anthropogenic climate change. Although temperature changes are less severe in aquatic habitats due to water's thermal properties (Bärlocher \& Boddy 2016), temperate streams are particularly affected influencing fungal attachment and colonisation rates, as well as metabolism, growth and reproduction (Canhoto et al. 2016). Alterations in the rates of these key lifecycle stages may affect community composition, diversity and activity (Hyde et al. 2016) which will have indirect effects on aquatic ecosystems due to the role of fungi in decomposition of organic matter and mediation of nutrient cycling and energy flow through aquatic food webs (Bärlocher 2016b, Kuehn 2016). 

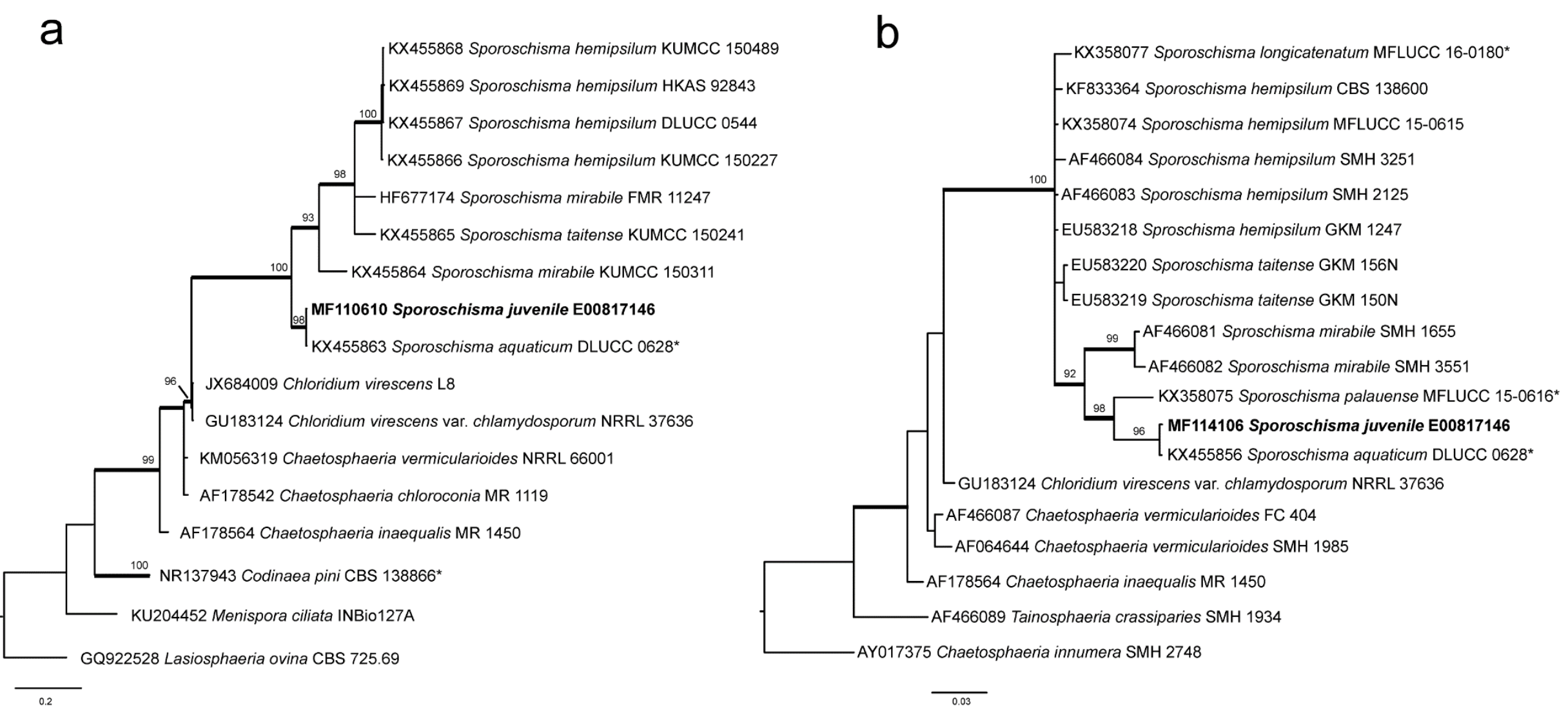

Fig. 8 Phylogenetic trees based on analyses of a) ITS and b) LSU rDNA. Bootstrap support values for Maximum Likelihood greater than $90 \%$ are indicated above the nodes. Bayesian posterior probabilities greater than 0.95 are shown as bold branches. The newly added strain is shown in bold, ex-type strains are indicated by an asterisk. 
Other anthropogenic stressors of aquatic habitats such as decreased dissolved $\mathrm{O}_{2}$ (Kuehn 2016), pollution (Tsui et al. 2001), acidification and physical disturbance (Hyde et al. 2016) may interact with temperature stress amplifying the negative effects (Kuehn 2016). Duarte et al. (2008) found that high aquatic fungal diversity mitigated the negative effects of pollution on decomposition highlighting the importance of maintaining diversity within aquatic ecosystems. Hyde et al. (2016) claim that terrestrial fungi cannot replace aquatic fungi should their diversity decline due to anthropogenic disturbances. Moreover, recent evidence of a terrestrial-endophytic stage of some waterborne anamorphic fungi (Selosse et al. 2008, Seena \& Monroy 2016) suggests that our knowledge of lifecycles of microfungi is very limited and any disturbance of the water environment may negatively affect also the terrestrial phase. Chalara spp, Mycocentrospora acerina, Neonectria lugdunensis, Sporochisma spp and Tetracladium setigerum, found in both aquatic and terrestrial environments (Ingold 1975, Shearer et al. 2007, Chauvet et al. 2016), are also found in this study. Anthropogenic influences on aquatic fungi are most likely negative and understanding subsequent consequences, and the relationships between aquatic and terrestrial fungi is vital to contribute to conservation and survival of aquatic ecosystems.

Similarity indices produced ambiguous results (Table 3) and taxa composition varies between each habitat (Table 1). This indicates that the fungi found are tolerant to temperature and salinity to varying degrees (Yuen et al. 1998). Taxa common to all three habitats include: Chalara state of $C$. parilis and Neonectria lugdunensis indicating that these species can tolerate wide salinity and temperature ranges. Similar species have been found by baiting in UK rivers (Willoughby \& Archer 1973, Iqbal \& Webster 1977, Shearer \& Webster 1991, Kane et al. 2002). Interestingly there are no taxa in common between this study and the study of Hyde and Goh (1999) in the river Coln, England. Willoughby \& Archer (1973) found a Fusarium sp. and Heliscus lugdunesis (synonym: Neonectria lugdunensis) after one month baiting and suggest these are early colonisers of submerged wood, whereas a Chalara sp. was found after seven months suggesting its later role in submerged wood colonisation succession.

Some taxa were only found in one habitat such as Anguilospora longissima and Menispora glauca in the river, Clonostachys sp.1 and Trichoderma sp. in the estuary and Tetracladium setigerum and Cryptocoryneum condensatum at the marine habitat. This possibly indicates that these species have narrow temperature requirements (Bärlocher \& Boddy 2016) and salinity ranges, or that they represent accidental occurrences (i.e. M. glauca is a typical terrestrial saprotroph). It is unlikely that abiotic factors measured in this limited study are solely responsible for the longitudinally varying distributions through one waterbody (Shearer \& Webster 1991). For example, T. setigerum has been found in freshwater environments in other studies (Willoughby \& Archer 1973).

Neonectria lugdunensis was recorded in both sexual and asexual states (Heliscus lugdunesis) (Willoughby \& Archer 1973, Bärlocher 2012). A further Fusarium-like synanamorph was recorded which corresponded with the Cylindrocarpon/Fusarium-like conidia known for N. lugdunensis (Webster 1959, Lombard et al. 2014) and the connection was confirmed with culture morphology and DNA sequences.

Sporochisma juvenile was found on submerged wood from the river habitat after 5 weeks of incubation at $4^{\circ} \mathrm{C}$. It has a wide-ranging distribution globally, based on morphological distributions. The IMI Herberium at Kew Gardens (HerbIMI, 2016) have records of S. juvenile from Great Britain, France and India. The known distribution of S. juvenile also includes: Australia, Czech Republic, Hong Kong, Peru and Seychelles (Holubová-Jechová 1973, Goh et al. 1997, Zelski et al. 2014). Evidently S. juvenile is able to colonise habitats with varying environmental conditions. The river habitat in which $S$. juvenile was found in this study had a water temperature of $3.89^{\circ} \mathrm{C}$ and $\mathrm{pH} 7.00$ whereas Zelski et al. (2014) found S. juvenile in water temperatures $9.7-22^{\circ} \mathrm{C}$ and $\mathrm{pH}$ 6-8.3 indicating the ranges of abiotic conditions in which $S$. 
juvenile is able to survive. The ability of $S$. juvenile to survive in varying environments may be facilitated by the ability of Sporoschisma to survive in terrestrial as well as aquatic habitats which may provide a reservoir during harsh environmental changes (Shearer et al. 2007).

Muller \& Samuels (1982) suggest, based on the Ellis (1971) description of S. juvenile, that it has a Chalara anamorph. However, it is evident that morphologically similar conidiogenous cells (venter and collarette - called phialides by Nag Raj \& Kendrick (1975)) can either produce hyaline, non-septate, conidia which later become pale brown, septate and verruculose (as in this study, both in culture and on the host, and illustrated by Ellis (1971) or condia which are already pale brown, septate and verruculose by the time they leave the collarette (e.g. Ellis 1971, Nag Raj \& Kendrick 1975, Hughes 1949). Luo et al. (2016) also illustrate similar behaviour in conidia of $S$. mirabile. The possible circumstances which cause condia to be so morphologically variable are discussed by Hughes (1949).

There is still much to be uncovered about evolution, diversity, distribution and activities of aquatic fungi (Vijaykrishna et al. 2006). In order to understand more about these important and complex organisms greater sampling efforts are needed globally combined with investigations of biotic and abiotic variables in sampled habitats. Furthermore, application of molecular techniques combined with the establishment and upkeep of fungal specific molecular databases may greatly improve the challenging identification steps and allow generation of large datasets to reveal patterns at local and global scales. Due to the role of fungi as facilitators of ecosystem processes it is important now more than ever to understand aquatic fungal ecosystems and particularly how they respond to stressors in light of changing global climates and anthropogenic disturbances.

\section{Acknowledgments}

We would like to thank Mingkwan Doilom for help with collecting. Ruth Hollands, Laura Forrest, Michelle Hart and Amanda Jones for assistance during molecular lab work. The Royal Botanic Garden Edinburgh (RBGE) is supported by the Scottish Government's Rural and Environmental Science and Analytical Services Division. During 2017 we are also grateful for the support of players of People's Postcode Lottery towards our scientific research. This study was supported by Institutional Support for Science and Research of the Ministry of Education, Youth and Sports of the Czech Republic.

\section{References}

Altschul SF, Gish W, Miller W, Myers EW, Lipman DJ. 1990 - Basic local alignment search tool. Jounal of Molecular Biology 215, 403-410

Bärlocher F. (Ed.). 2012 - The ecology of aquatic hyphomycetes (Vol. 94). Springer Science $\&$ Business Media.

Bärlocher F. \& Boddy L. 2016a - Aquatic fungal ecology - How does it differ from terrestrial? Fungal Ecology 19, 5-13.

Bärlocher F. 2016b - Aquatic hyphomycetes in a changing environment. Fungal Ecology 19, 14-27.

Baschien C, Manz W, Neu TR, Marvanová L, Szewzyk U. 2008- In situ detection of freshwater fungi in an alpine stream by new taxon-specific fluorescence in situ hybridization probes. Applied and Environmental Microbiology 74, 6427-6436.

Boudier JLE. 1904 - Icones mycologicae ou iconographie des champignons de France, principalement Discomycètes. Vol. 3. Editions Piantanida Lausanne (1981).

Canhoto C, Gonçalves AL, Bärlocher F. 2016 - Biology and ecological functions of aquatic hyphomycetes in a warming climate. Fungal Ecology 19, 201-218.

Chauvet E, Cornut J, Sridhar KR, Selosse MA, Bärlocher F. 2016 - Beyond the water column: aquatic hyphomycetes outside their preferred habitat. Fungal Ecology 19, 112-127. 
Cubero OF, Crespo ANA, Fatehi J, Bridge PD. 1999 - DNA extraction and PCR amplification method suitable for fresh, herbarium-stored, lichenized, and other fungi. Plant Systematics and Evolution 216, 243-249.

Darriba D, Taboada GL, Doallo R, Posada D. 2012 - jModelTest 2: more models, new heuristics and parallel computing. Nature Methods 9, 772.

Dennis RWG. 1964 - The fungi of the Isle of Rhum. Kew Bulletin 19: 77-127.

Duarte S, Pascoal C, Cássio F. 2008 - High diversity of fungi may mitigate the impact of pollution on plant litter decomposition in streams. Microbial ecology 56, 688-695.

Ellis MB. 1971 - Dematiaceous Hyphomycetes, Issue 125. Commonwealth Mycological Insitute.

Fernandes I, Pascoal C, Guimaraes H, Pinto R et al. 2012 - Higher temperature reduces the effects of litter quality on decomposition by aquatic fungi. Freshwater Biology 57 , 2306-2317.

Fournier J, Raja HA, Shearer CA. 2015 - Freshwater Ascomycetes: Jahnula purpurea (Jahnulales, Dothideomycetes), a new species on submerged wood from Martinique Island, Lesser Antilles. MycoKeys 9, 29-36.

Fryar SC, Booth W, Davies J, Hodgkiss IJ, Hyde KD. 2004 - Distribution of fungi on wood in the Tutong River, Brunei. Fungal Diversity 17, 17-38.

Geraldes P, Pascoal C, Cássio F. 2012 - Effects of increased temperature and aquatic fungal diversity on litter decomposition. Fungal Ecology 5, 734-740.

Goh TK, Ho WH, Hyde KD, Umali TE. 1997 - New records and species of Sporoschisma and Sporoschismopsis from submerged wood in the tropics. Mycological Research 101, 1295-1307

Gray JR. 2004 - Conductivity Analyzers and Their Application, in Environmental Instrumentation and Analysis Handbook (eds R. D. Down and J. H. Lehr), John Wiley \& Sons, Inc., Hoboken, NJ, USA.

HerbIMI $2016 \quad-\quad$ Royal Botanic Gardens, Kew. http://www.herbimi.info/herbimi/results.htm?name=Sporoschisma\%20juvenile (Accessed: 17 November 2016).

Ho WH, Hodgkiss IJ. 2001 - Fungal communities on submerged wood from streams in Brunei, Hong Kong, and Malaysia. Mycological Research 105, 1492-1501.

Ho WH, Yanna, Hyde KD, Hodgkiss IJ. 2002 - Seasonality and sequential occurrence of fungi on wood submerged in Tai Po Kau Forest Stream, Hong Kong. In: Fungal Succession (eds. K.D. Hyde and E.B.G. Jones). Fungal Diversity 10, 21-43.

Holubová-Jechová V. 1973 - Lignicolous Hyphomycetes from Czechoslovakia 3. Sporoschisma, Sporoschismopsis and Catenularia. Folia Geobotanica et Phytotaxonomica 8, 209-218

Hughes SJ. 1949. - Studies on Micro-fungi: The genus Sporoschisma Berkeley \& Broome: and a re-description of Helminthosporium rousellianum Montagne. II. Mycological Papers. $31,1-34$.

Hyde KD, Goh TK. 1999 - Fungi on submerged wood from the River Coln, England. Mycological Research 103, 1561-1574.

Hyde KD, Fryar S, Tian Q, Bahkali AH, Xu J. 2016 - Lignicolous freshwater fungi along a north-south latitudinal gradient in the Asian/Australian region; can we predict the impact of global warming on biodiversity and function? Fungal Ecology 19, 190-200.

Ingold CT. 1942 - Aquatic hyphomycetes of decaying alder leaves. Transactions of the British Mycological Society 25, 339-IN6.

Ingold CT. 1973 - Aquatic hyphomycete spores from West Scotland. Transactions of the British Mycological Society 61, 251-255. 
Ingold CT. 1975 - Illustrated guide to aquatic and water-borne Hyphomycetes (Fungi imperfecti) with notes on their biology. Scientific publication.

Iqbal SH, Webster J. 1977 - Aquatic hyphomycete spora of some Dartmoor streams. Transactions of the British Mycological Society 69, 233-241.

Jones EG. 2011 - Fifty years of marine mycology. Fungal diversity 50, 73-112

Jones EG, Hyde KD, Pang KL (Eds.). 2014 - Freshwater fungi: and fungal-like organisms. Walter de Gruyter GmbH \& Co KG.

Kane DF, Tam WY, Jones EBG. 2002 - Fungi colonising and sporulating on submerged wood in the River Severn, UK. Fungal Diversity 10, 45-55.

Keylock CJ. 2005 - Simpson diversity and the Shannon-Wiener index as special cases of a generalized entropy. Oikos 109, 203-207.

Kõljalg U, Nilsson RH, Abarenkov K, Tedersoo L et al. 2013 - Towards a unified paradigm for sequence-based identification of fungi. Molecular Ecology 22, 5271-5277.

Koukol O. 2011 - New species of Chalara occupying coniferous needles. Fungal Diversity 49, 75-91.

Krebs CJ. 2014 - Ecological Methodology, 3rd ed. Addison-Wesley Educational Publishers, Inc.

Kuehn KA. 2016 - Lentic and lotic habitats as templets for fungal communities: traits, adaptations, and their significance to litter decomposition within freshwater ecosystems. Fungal Ecology 19, 135-154.

Kumar S, Stecher G, Tamura K. 2016 - MEGA7: Molecular Evolutionary Genetics Analysis version 7.0 for bigger datasets. Molecular Biology and Evolution, p.msw054.

Larena I, Salazar O, González V, Julián MC, Rubio V. 1999 - Design of a primer for ribosomal DNA internal transcribed spacer with enhanced specificity for ascomycetes. Journal of Biotechnology 75,187-194.

Lenntech 2016 - Water conductivity, http://www.lenntech.com/applications/ultrapure/ conductivity/water-conductivity.htm (Accessed: 29th March 2016).

Lewis EL, Perkin RG. 1978 - Salinity: its definition and calculation. Journal of Geophysical Research: Oceans 83, 466-478.

Lombard L, Van Der Merwe NA, Groenewald JZ, Crous PW. 2014 - Lineages in Nectriaceae: re-evaluating the generic status of Ilyonectria and allied genera. Phytopathologia Mediterranea 53, 515-532.

Luo Z.L, Bao D.F, Bhat JD, Yang J et al. 2016 - Sporoschisma from submerged wood in Yunnan, China. Mycological Progress 15, 1145-1151.

McKenzie EH, Pinnoi A, Wong M, Hyde KD, Jones EG. 2002 - Two new hyaline Chalara species and a key to species described since 1975. Fungal Diversity 11, 129-139.

Medeiros AO, Pascoal C, Graça MAS. 2009 - Diversity and activity of aquatic fungi under low oxygen conditions. Freshwater Biology 54, 142-149.

Muller E, Samuels GJ. 1982 - Anamorphs of pyrenomycetous Ascomycetes III. The Sporoschisma and Chalara anamorphs of Melanochaeta aotearoae. Sydowia 155-161.

Nag Raj TR, Kendrick B. 1975 - A monograph of Chalara and Allied Genera. Wilfred Laurier University Press.

O'Brien HE, Parrent JL, Jackson JA, Moncalvo JM, Vilgalys R. 2005 - Fungal community analysis by large-scale sequencing of environmental samples. Applied and Environmental Microbiology 71, 5544-5550.

O’Donnell K. 1993 - Fusarium and its near relatives. In The Fungal Holomorph: Mitotic, Meiotic and Pleomorphic Speciation in Fungal Systematics, pp. 225-233. Edited by D. R. Reynolds \& J. W. Taylor. Wallingford, UK: CAB International.

Pearman JK, Taylor JE, Kinghorn JR. 2010 - Fungi in aquatic habitats near St Andrews in Scotland. Mycosphere 1, 11-21. 
Peet RK. 1975 - Relative diversity indices. Ecology, 496-498.

Pielou EC. 1966 - Shannon's formula as a measure of specific diversity: its use and misuse. The American Naturalist 100, 463-465.

Réblová M. 2014 - Sporoschismopsis angustata sp. nov., a new holomorph species in the Reticulascaceae (Glomerellales), and a reappraisal of Sporoschismopsis. Mycological Progress 13, 671-681.

Réblová M, Fournier J, Štěpánek V. 2015a - Pisorisporiales, a new order of aquatic and terrestrial fungi for Achroceratosphaeria and Pisorisporium gen. nov. in the Sordariomycetes. Persoonia 34, 40-49.

Réblová M, Fournier J, Štěpánek V. 2016 - Two new lineages of aquatic ascomycetes: Atractospora gen. nov. and Rubellisphaeria gen. et sp. nov., and a sexual morph of Myrmecridium montsegurinum sp. nov. Mycological Progress 15, 1-18.

Richards TA, Jones MD, Leonard G, Bass D. 2012 - Marine fungi: their ecology and molecular diversity. Annual Review of Marine Science 4, 495-522.

Ronquist F, Teslenko M, van der Mark P, Ayres DL et al. 2012 - MrBayes 3.2: efficient Bayesian phylogenetic inference and model choice across a large model space. Systematic Biology 61, 539-542

Seena S, Monroy S. 2016 - Preliminary insights into the evolutionary relationships of aquatic hyphomycetes and endophytic fungi. Fungal Ecology 19, 128-134.

Selosse MA, Vohník M, Chauvet E. 2008 - Out of the rivers: are some aquatic hyphomycetes plant endophytes? New Phytologist 178, 3-7.

Shannon CE, Weaver W. 1949 - The mathematical theory of communication. The University of Illinois Press, Urbana, 117.

Shearer CA. 1972 - Fungi of the Chesapeake Bay and its tributaries. III. The distribution of wood-inhabiting Ascomycetes and Fungi Imperfecti of the Patuxent River. American Journal of Botany 59, 961-969.

Shearer C, Webster J. 1985a - Aquatic hyphomycete communities in the River Teign I. Longitudinal distribution patterns. Transactions of the British Mycological Society 84, 489-501.

Shearer C, Webster J, 1985b - Aquatic hyphomycete communities in the River Teign. II. Temporal distribution patterns. Transactions of the British Mycological Society 84, 503-507.

Shearer CA, Webster J. 1991 - Aquatic hyphomycete communities in the River Teign. IV. Twig colonization. Mycological Research 95, 413-420.

Shearer CA, Descals E, Kohlmeyer B, Kohlmeyer J et al. 2007 - Fungal biodiversity in aquatic habitats. Biodiversity Conservation 16, 49-67.

Sokolski S, Piché Y, Laitung B, Bérubé JA. 2006 - Streams in Quebec boreal and mixed-wood forests reveal a new aquatic hyphomycete species, Dwayaangam colodena sp. nov. Mycologia 98, 628-636

Sørensen T. 1948 - A method of establishing groups of equal amplitude in plant sociology based on similarity of species and its application to analyses of the vegetation on Danish commons. Biologiske Skrifter 5, 1-34.

Svrček M. 1984 - A taxonomic revision of inoperculate discomycetes described by J. Velenovský in the genus Helotium, preserved in National Museum, Prague. Acta Musei Nationalis Pragae 40B, 129-215.

Tsui KM, Hyde KD, Hodgkiss IJ. 2000 - Biodiversity of fungi on submerged wood in Hong Kong streams. Aquatic Microbial Ecology 21, 289-298.

Tsui KM, Hyde KD, Hodgkiss IJ. 2001 - Longitudinal and temporal distribution of freshwater ascomycetes and dematiaceous hyphomycetes on submerged wood in the Lam Tsuen River, Hong Kong. Journal of the North American Benthological Society 20, 533-549. 
Tsui KM, Hyde KD. 2004 - Biodiversity of fungi on submerged wood in a stream and estuary in the Tai Ho Bay, Hong Kong. Fungal Diversity 15, 205-220.

Van der Heijden MG, Klironomos JN, Ursic M, Moutoglis P et al. 1998 - Mycorrhizal fungal diversity determines plant biodiversity, ecosystem variability and productivity. Nature 396, 69-72.

Vijaykrishna D, Jeewon R, Hyde KD. 2006 - Molecular taxonomy, origins and evolution of freshwater ascomycetes. Fungal Diversity 23, 351-390.

Webster J, 1959 - Nectria lugdunensis sp. nov., the perfect state of Heliscus lugdunensis. Transactions of the British Mycological Society 42, 322-327.

White TJ, Bruns T, Lee SJWT, Taylor JW. 1990 - Amplification and direct sequencing of fungal ribosomal RNA genes for phylogenetics. PCR protocols: a guide to methods and applications 18, 315-322.

Willoughby LG, Archer JF. 1973 - The fungal spora of a freshwater stream and its colonization pattern on wood. Freshwater Biology 3, 219-239.

Wong MK, Goh TK, Hodgkiss IJ, Hyde KD et al. 1998 - Role of fungi in freshwater ecosystems. Biodiversity \& Conservation 7, 1187-1206.

Yuen T, Hyde KD, Hodgkiss IJ. 1998 - Physiological growth parameters and enzyme production in tropical freshwater fungi. Material und Organismen (Germany) 1, 1-16.

Zelski SE, Balto JA, Do C, Raja HA et al. 2014 - Phylogeny and morphology of dematiaceous freshwater microfungi from Perú. IMA Fungus 5, 425-438.

Zhang J, Zhou Y, Dou Z, Fournier J, Zhang Y. 2015 - Helicascus unilocularis sp. nov., a new freshwater pleosporalean ascomycete from the Caribbean area. Mycological Progress 14, 1-8. 